\title{
Population Dynamics of Plant-Parasitic Nematodes in Golf Course Greens Turf in Southern New England
}

\author{
K. S. Jordan, Graduate Research Assistant, and N. A. Mitkowski, Assistant Professor, Department of Plant Sci- \\ ences, University of Rhode Island, Kingston 02881
}

\begin{abstract}
Jordan, K. S., and Mitkowski, N. A. 2006. Population dynamics of plant-parasitic nematodes in golf course greens turf in southern New England. Plant Dis. 90:501-505.

The distribution, frequency, and population levels over time of plant-parasitic nematodes were surveyed on 114 greens from 38 different golf courses throughout southern New England. Sampling took place in the spring, summer, and fall of 2003 and 2004. The predominant genera of phytoparasitic nematodes recovered from soil samples were Tylenchorhynchus, Helicotylenchus, Criconemella, Hoplolaimus, and Heterodera. Tylenchorhynchus and Helicotylenchus spp. were the most common, found in all 38 golf courses sampled. Population levels were significantly higher $(\alpha=0.05)$ in 2004 than in 2003 for Criconemella, Tylenchorhynchus, and Heterodera juveniles. There was a significant effect of season on population levels of Criconemella, Tylenchorhynchus, and Heterodera juveniles in the 2003 sampling year, and on Helicotylenchus, Tylenchorhynchus, and Heterodera juveniles in 2004. Population levels were highest in the fall for all genera except for Tylenchorhynchus, which were highest in the summer for both years. The results of this study suggest that parasitic nematodes are present in relatively high numbers in golf course turf soils in southern New England, and that there are variations in the dynamics of population levels among the different genera found in the area.
\end{abstract}

Nematodes are known to be important pests of turfgrass in the southern regions of the United States $(14,24)$, but their importance in the north is not as clearly understood (15). Nematodes attack the roots of turfgrass plants, leading to a decrease in the uptake of water and nutrients. Over time, affected plants exhibit a reduction in vigor. In the southern United States, turf is grown year-round, providing a constant source of food for plant-parasitic nematodes. This allows for year-long reproduction and, consequently, the potential for high population levels to be reached in a relatively short period of time (10). Nematodes are rarely considered to be a problem of turfgrass in the northern regions of North America, in part due to the delayed onset of symptoms, which makes it difficult to link damage to nematode feeding. However, under stressful situations such as extreme soil compaction, excessive traffic, and particularly drought, the decrease in root mass caused by nematode damage leads to a fairly rapid decline in plant health. Unfortunately, definitive diagnosis of the problem still may be difficult because the symptoms of nematode damage-including yellowing and thinning of

Corresponding author: N. A. Mitkowski

E-mail: mitkowski@uri.edu

Accepted for publication 16 November 2005.

DOI: 10.1094/PD-90-0501

(C) 2006 The American Phytopathological Society turf and reduced resistance to stresses-are relatively nonspecific $(12,16)$. When nematodes are found to be the cause of decline in turf quality, turfgrass managers have a limited number of control methods at their disposal (12). A keen understanding of the trends in population changes over time, along with a knowledge of the predominant parasitic nematodes that are present in soils in the region, can aid in proper management and, if necessary, control of these pathogens $(1,6)$. Population dynamics surveys conducted in various regions of central and northern United States have indicated the presence of numerous genera of plant-parasitic nematodes on turfgrass $(3,11,17-20)$. Murdoch et al. (11) recovered 10 genera of phytoparasitic nematodes from putting greens throughout New York, while 11 known plant-parasitic nematode genera were recovered from putting greens in Kansas (19). Similar studies have shown a high diversity of genera of parasitic nematodes in regions of Canada as well (25). To date, there have been two published studies of nematode population dynamics in the New England region $(20,23)$. Since the time of these publications, golf has become increasingly popular and, in the mid- to late 1990s, there was a boom of golf course construction in the New England region (National Golf Foundation, personal communication). Additionally, management practices have become more intense on golf courses in the past few decades, as has the trend toward sand-based greens construction (4). These changes tend to be favorable for an increase in nematode populations and the potential for damage to turfgrass (12). The purpose of this study was to survey the distribution and frequency of occurrence of plant-parasitic nematodes on a variety of golf course greens in southern New England and to determine the dynamics of nematode populations over time, both within a growing season and between two different seasons.

\section{MATERIALS AND METHODS}

Sample collection. Samples were collected from 114 mixed bentgrass (both creeping [Agrostis palustris Huds.] and velvet $[$ A. canina $\mathrm{L}]$.$) and annual bluegrass$ (Poa апnиа L.) putting greens at 38 golf courses throughout the southern New England region (Table 1) during the 2003 and 2004 growing seasons. The geographical distribution of the sampling sites is shown in Figure 1. Samples were taken in May, June, and September of both years. Golf courses were chosen based on previous nematode data obtained from the University of Rhode Island turfgrass diagnostic clinic. Sites were chosen such that there was a relatively even mix of courses that had historically high levels of nematodes and those that had low levels. Three greens from each golf course were chosen at random or at the discretion of the superintendent on site. Greens were sampled by collecting 20 to 30 cores-depending on green size-evenly spaced throughout the green using a $1.9-\mathrm{cm}$-diameter soil probe. Cores were taken to a depth of $10.2 \mathrm{~cm}$, and the top $2.5 \mathrm{~cm}$ of turf and thatch were removed and returned to the green. Cores were placed in a plastic sample bag to create one composite sample for each green. All samples were kept at $4^{\circ} \mathrm{C}$ and were extracted within a 2 -week period.

Nematode extraction and identification. Composite samples were sieved through a $0.635-\mathrm{cm}$ sieve and mixed thoroughly. A $25-\mathrm{cm}^{3}$ subsample was used for extraction. Nematodes were extracted using a modification of the sugar flotation centrifugal method (8). Nematodes were identified to genus level using a dissecting microscope and data was recorded as the number of nematodes per $100 \mathrm{~cm}^{3}$ of soil.

Data analysis. Analysis of population levels of each genus between golf courses, sampling seasons within each year, and sampling years was performed. All data were tested for analysis of variance assumptions. Comparisons between golf 
courses were made using the general linear models procedure and the Waller-Duncan means comparison test in SPSS (Chicago). Data for sampling season and year were found to be non-normal; therefore, the Kruskal-Wallis and Mann-Whitney nonparametric tests were performed in SPSS to compare treatment differences.

Table 1. Site key to golf courses sampled ${ }^{z}$

\begin{tabular}{|c|c|c|c|}
\hline Site no. & Golf course & Location & Greens sampled \\
\hline 1 & Wee Burn CC & Darien, CT & $4,12,14$ \\
\hline 2 & Woodway CC & Darien, CT & $2,14,15$ \\
\hline 3 & Oak Hills Park GC & Norwalk, CT & $2,12,16$ \\
\hline 4 & Patterson CC & Fairfield, CT & $5,9,11$ \\
\hline 5 & Manchester CC & Manchester, CT & $8,12,13$ \\
\hline 6 & Cedar Ridge GC & East Lyme, CT & $3,12,17$ \\
\hline 7 & Pequot GC & Stonington, CT & $1,9,18$ \\
\hline 8 & Misquamicut Club & Watch, Hill, RI & $2,12,15$ \\
\hline 9 & Weekapaug Golf Club & Westerly, RI & $3,5,6$ \\
\hline 10 & Foxwoods Golf \& CC & Richmond, RI & $1,2,9$ \\
\hline 11 & Beaver River Golf Club & Richmond, RI & $4,8,12$ \\
\hline 12 & Laurel Lane CC & W. Kingston, RI & $7,10,14$ \\
\hline 13 & Jamestown CC & Jamestown, RI & $7,8,9$ \\
\hline 14 & Green Valley CC & Portsmouth, RI & $3,15,18$ \\
\hline 15 & Sakonnet Golf Club & Little Compton, RI & $2,15,18$ \\
\hline 16 & Rhode Island CC & Barrington, RI & $2,18, \mathrm{PG}$ \\
\hline 17 & Potowomut CC & East Greenwich, RI & $8,16,18$ \\
\hline 18 & Woodland Greens Golf Club & North Kingstown, RI & $5,7,8$ \\
\hline 19 & Quidnessett CC & North Kingstown, RI & $1,2,9$ \\
\hline 20 & Midville Golf Club & West Warwick, RI & $1,5,6$ \\
\hline 21 & West Warwick CC & West Warwick, RI & $4,6, \mathrm{PG}$ \\
\hline 22 & Cranston CC & Cranston, RI & $3,9, \mathrm{PG}$ \\
\hline 23 & Warwick CC & Warwick, RI & $4,6, P G$ \\
\hline 24 & Foster CC & Foster, RI & $11,17,18$ \\
\hline 25 & Glocester CC & Glocester, RI & $1,2,9$ \\
\hline 26 & Pawtucket CC & Seekonk, MA & $9,12,16$ \\
\hline 27 & Firefly GC & Seekonk, MA & $4,9,13$ \\
\hline 28 & Ledgemont CC & Seekonk, MA & $2,8,10$ \\
\hline 29 & Crestwood CC & Rehoboth, MA & $2,4,10$ \\
\hline 30 & Milton Hoosic Club & Canton, MA & $2,8,9$ \\
\hline 31 & Blue Hill CC & Canton, MA & $11,12,13$ \\
\hline 32 & Duxbury CC & Duxbury, MA & $4,10,17$ \\
\hline 33 & Dedham Country \& Polo Club & Westwood, MA & $9,11, \mathrm{PG}$ \\
\hline 34 & Oakley CC & Watertown, MA & $2,12,13$ \\
\hline 35 & Bear Hill CC & Stoneham, MA & $1,5,7$ \\
\hline 36 & Pine Brook CC & Weston, MA & $7,9,11$ \\
\hline 37 & Ferncroft CC & Danvers, MA & $6,7,10$ \\
\hline 38 & Myopia Hunt Club & South Hamilton, MA & $7,12,15$ \\
\hline
\end{tabular}

${ }^{\mathrm{z}} \mathrm{CC}=$ country club, $\mathrm{GC}=$ golf course.

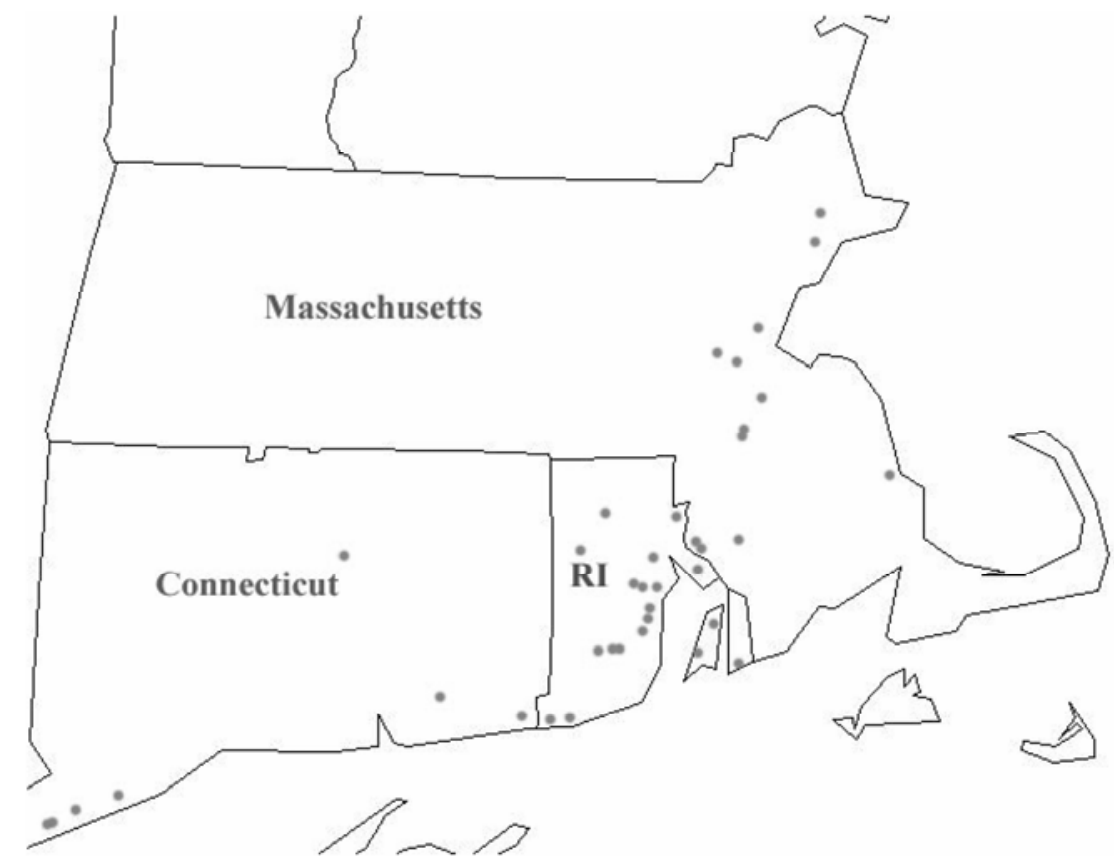

Fig. 1. Distribution of golf courses sampled throughout southern New England.

\section{RESULTS}

Plant-parasitic nematodes were found in all of the samples tested. The five dominant genera recovered from the soil samples were Tylenchorhynchus, Helicotylenchus, Criconemella, Hoplolaimus, and Heterodera juveniles. There also were a small number of samples that had Meloidogyne juveniles and other stylet-bearing nematodes, including Pratylenchus and Tylenchus. The results show significant variability in the population levels of phytoparasitic nematodes between the golf courses tested (Table 2). Data on the frequency of occurrence of each genus on the golf courses and in the samples, as well as which nematodes were found above threshold levels (based on data from R. Wick at the University of Massachusetts), are displayed in Table 3. Tylenchorhynchus spp. were found in all golf course samples tested and were above threshold in approximately one-third of the samples tested. Helicotylenchus and Criconemella spp. were the next most frequent, followed by Hoplolaimus and Heterodera spp. Meloidogyne spp. and other stylet-bearing nematodes were found in only one-third of the samples tested, and in small quantities at each site. Seasonal fluctuation was observed in the first sampling year within the genera Criconemella, Tylenchorhynchus, and Heterodera $(P<0.01$; Fig. 2). Tylenchorhynchus population levels were highest in the June sampling date, whereas Criconemella and Heterodera levels were highest in September. The other two predominant genera showed no significant change from one sampling period to the other in 2003. In the 2004 season, there was a significant effect of sampling date on nematode populations for Helicotylenchus, Tylenchorhynchus, and Heterodera spp. $(P<0.05)$. Criconemella, Helicotylenchus, and Heterodera population levels all were highest in September, and Tylenchorhynchus levels were highest in June. Seasonal fluctuation for Meloidogyne spp. is not reported because root-knot nematodes were counted only during the fall 2004 sampling date. Non-stylet-bearing nematodes also were counted during the 2004 season in an attempt to determine seasonal fluctuation of nonphytoparasitic nematodes, and to see if there was any correlation between levels of plantparasitic nematodes and non-stylet-bearing nematodes. The non-stylet-bearing nematodes increased significantly in the summer sampling and remained constant in the fall sampling date (Fig. 2). Levels of nonphytoparasitic nematodes were positively correlated with Criconemella populations $\left(r^{2}=0.129, P=0.017\right)$ and Tylenchorhynchus nematode populations $\left(r^{2}=0.491, P\right.$ $=0.000)$. There was a significant effect of sampling year as well. Population levels of Tylenchorhynchus, Criconemella, and Heterodera spp. all were significantly higher in the 2004 season $(P=0.000)$. 
Although nematode levels appeared higher in Helicotylenchus and Hoplolaimus spp. as well, these differences were not significant.

\section{DISCUSSION}

Studies involving population dynamics often are conducted in an attempt to predict nematode behavior in a particular field or in a larger region in the hopes of extrapolating that information to other regions of similar characteristics (crop, average temperature, moisture, and so on; 13). Additionally, information obtained about population fluctuations can be used to accurately time chemical applications or to adjust management practices in areas where nematodes may be a threat to healthy turf (1). Comparison of data from one region to another allows for wider projection of data and more accurate interpretations of the data obtained in an individual study.

The genera of plant-parasitic nematodes found in this survey were similar to those found in other studies done in the northern and central regions of the United States $(11,19,23)$, as well as in some parts of Canada (7). The high prevalence of Tylenchorhynchus spp. in the New England region was consistent with findings by Troll and Tarjan (20), although the other nematodes frequently found in that study, including Pratylenchus and Tylenchus spp., were not as prevalent in this one. The results of this study suggest that nematodes are found in high numbers in the southern New England region of the United States, and that the number of samples with nematodes above threshold could indicate a potential problem in this region.

Table 3. Frequency of occurrence of nematodes and nematodes above threshold on golf courses and greens

\begin{tabular}{lccc}
\hline & \multicolumn{2}{c}{ With nematodes $(\%)$} & \\
\cline { 2 - 3 } Nematode genus & Golf courses & Greens & Samples above threshold $(\%))^{\mathbf{y}}$ \\
\hline Criconemella & 97.4 & 95.6 & 7.0 \\
Helicotylenchus & 100.0 & 98.2 & 2.6 \\
Tylenchorhynchus & 100.0 & 100.0 & 35.1 \\
Hoplolaimus & 89.5 & 85.1 & 9.6 \\
Heterodera $^{\mathrm{z}}$ & 94.7 & 84.2 & 7.9 \\
Meloidogyne $^{\mathrm{z}}$ & 50.0 & 31.6 & 1.8 \\
Other parasitic genera & 76.3 & 39.5 & NA \\
\hline
\end{tabular}

y Threshold data based on findings from University of Massachusetts Turf Diagnostics Lab refers to nematode levels above threshold at any of the six sampling dates in 2003 and 2004; NA = not applicable.

${ }^{\mathrm{z}}$ Value refers to juveniles recovered from soil.

Table 2. Mean nematode values at each course for each nematode genus or type identified, based on peak population sampling date for each nematode

\begin{tabular}{|c|c|c|c|c|c|c|c|c|c|c|c|c|}
\hline \multirow[b]{3}{*}{ Site $^{\mathrm{z}}$} & \multicolumn{12}{|c|}{ Nematode, season ${ }^{y}$} \\
\hline & \multicolumn{2}{|c|}{ Cric, fall } & \multicolumn{2}{|c|}{ Helic, fall } & \multicolumn{2}{|c|}{ Tylen, summer } & \multicolumn{2}{|c|}{ Hoplo, fall } & \multicolumn{2}{|c|}{ Het $\mathrm{J}$, fall } & \multirow{2}{*}{$\frac{\text { Melo J, fall }}{2004}$} & \multirow{2}{*}{$\begin{array}{l}\text { NSB } \\
2004\end{array}$} \\
\hline & 2003 & 2004 & 2003 & 2004 & 2003 & 2004 & 2003 & 2004 & 2003 & 2004 & & \\
\hline 1 & 275 abcde & $893 \mathrm{e}$ & $243 a b$ & $1,407 \mathrm{c}$ & $153 \mathrm{abc}$ & 593 abcde & 80 abcd & 147 abcde & $13 \mathrm{a}$ & $7 \mathrm{a}$ & $0 \mathrm{a}$ & 647 fghij \\
\hline 2 & 313 abcde & $720 \mathrm{cde}$ & $1,180 \mathrm{~d}$ & $3,827 \mathrm{~d}$ & $92 \mathrm{ab}$ & $1,060 \mathrm{ef}$ & $0 \mathrm{a}$ & $33 \mathrm{ab}$ & $67 \mathrm{bc}$ & $47 \mathrm{a}$ & $0 \mathrm{a}$ & 420 cdefg \\
\hline 3 & $77 \mathrm{ab}$ & 447 abcde & $185 \mathrm{a}$ & $1,027 \mathrm{bc}$ & $17 \mathrm{a}$ & $127 \mathrm{abc}$ & $11 \mathrm{a}$ & $73 \mathrm{abcd}$ & $16 a b c$ & $127 \mathrm{abc}$ & $0 \mathrm{a}$ & 523 efghi \\
\hline 4 & $59 \mathrm{a}$ & $203 \mathrm{abcd}$ & $9 \mathrm{a}$ & $50 \mathrm{a}$ & $21 \mathrm{a}$ & $263 \mathrm{abcd}$ & $0 \mathrm{a}$ & $10 \mathrm{a}$ & $55 \mathrm{abc}$ & $223 \mathrm{c}$ & $0 \mathrm{a}$ & $770 \mathrm{hij}$ \\
\hline 5 & $911 \mathrm{gh}$ & $2,860 \mathrm{~g}$ & $8 \mathrm{a}$ & $253 \mathrm{a}$ & $5 \mathrm{a}$ & 244 abcd & $13 \mathrm{ab}$ & $60 \mathrm{abc}$ & $3 \mathrm{a}$ & $13 \mathrm{a}$ & $0 \mathrm{a}$ & $150 \mathrm{abc}$ \\
\hline 6 & $97 \mathrm{abc}$ & $149 \mathrm{abcd}$ & $1 \mathrm{a}$ & $11 \mathrm{a}$ & $12 \mathrm{a}$ & $113 a b c$ & $51 \mathrm{abc}$ & $87 \mathrm{abcd}$ & $3 \mathrm{a}$ & $1 \mathrm{a}$ & $5 \mathrm{ab}$ & $119 \mathrm{abc}$ \\
\hline 7 & $45 \mathrm{a}$ & $107 \mathrm{abc}$ & $123 \mathrm{a}$ & $1,313 \mathrm{c}$ & $11 \mathrm{a}$ & $253 \mathrm{abcd}$ & $12 \mathrm{ab}$ & $33 \mathrm{ab}$ & $0 \mathrm{a}$ & $27 \mathrm{a}$ & $47 \mathrm{ab}$ & 270 abcde \\
\hline 8 & $181 \mathrm{abc}$ & 283 abcde & $787 \mathrm{abc}$ & $550 \mathrm{ab}$ & $69 \mathrm{ab}$ & 683 bcde & $7 \mathrm{a}$ & $17 \mathrm{a}$ & $0 \mathrm{a}$ & $80 a b c$ & $17 \mathrm{ab}$ & $880 \mathrm{jk}$ \\
\hline 9 & $0 \mathrm{a}$ & $0 \mathrm{a}$ & $584 \mathrm{bc}$ & $579 \mathrm{ab}$ & $52 \mathrm{ab}$ & $47 \mathrm{a}$ & $13 \mathrm{ab}$ & $17 \mathrm{a}$ & $0 \mathrm{a}$ & $0 \mathrm{a}$ & $17 \mathrm{ab}$ & 273 abcde \\
\hline 10 & $1 \mathrm{a}$ & $0 \mathrm{a}$ & $0 \mathrm{a}$ & $4 \mathrm{a}$ & $0 \mathrm{a}$ & $21 \mathrm{a}$ & $0 \mathrm{a}$ & $0 \mathrm{a}$ & $0 \mathrm{a}$ & $0 \mathrm{a}$ & $0 \mathrm{a}$ & $144 a b c$ \\
\hline 11 & $0 \mathrm{a}$ & $1 \mathrm{a}$ & $0 \mathrm{a}$ & $4 \mathrm{a}$ & $0 \mathrm{a}$ & $1 \mathrm{a}$ & $0 \mathrm{a}$ & $0 \mathrm{a}$ & $0 \mathrm{a}$ & $0 \mathrm{a}$ & $0 \mathrm{a}$ & $20 \mathrm{a}$ \\
\hline 12 & $25 \mathrm{a}$ & $100 \mathrm{abc}$ & $212 \mathrm{a}$ & 289 a & $11 \mathrm{a}$ & 227 abcd & $0 \mathrm{a}$ & $0 \mathrm{a}$ & $0 \mathrm{a}$ & $8 \mathrm{a}$ & $3 \mathrm{ab}$ & 170 abcd \\
\hline 13 & $61 \mathrm{a}$ & 365 abcde & $44 \mathrm{a}$ & $3 \mathrm{a}$ & $15 \mathrm{a}$ & $104 a b c$ & $0 \mathrm{a}$ & $0 \mathrm{a}$ & $0 \mathrm{a}$ & $132 \mathrm{abc}$ & $53 a b c$ & 231 abcde \\
\hline 14 & $1,267 \mathrm{~h}$ & $1,953 \mathrm{f}$ & $47 \mathrm{a}$ & $33 \mathrm{a}$ & $20 \mathrm{a}$ & $67 \mathrm{ab}$ & $173 \mathrm{cde}$ & 100 abcde & $7 \mathrm{a}$ & $20 \mathrm{a}$ & $107 \mathrm{c}$ & 380 bcdefg \\
\hline 15 & $0 \mathrm{a}$ & $9 \mathrm{a}$ & $33 \mathrm{a}$ & $31 \mathrm{a}$ & 732 ef & $1,400 \mathrm{f}$ & $7 \mathrm{a}$ & $5 \mathrm{a}$ & $0 \mathrm{a}$ & $41 \mathrm{a}$ & $7 \mathrm{ab}$ & 473 defgh \\
\hline 16 & $1 \mathrm{a}$ & $17 \mathrm{a}$ & $132 \mathrm{a}$ & $393 \mathrm{a}$ & $571 \mathrm{de}$ & $940 \mathrm{ef}$ & $87 \mathrm{abcd}$ & 120 abcde & $0 \mathrm{a}$ & $57 \mathrm{ab}$ & $47 \mathrm{ab}$ & 333 abcdef \\
\hline 17 & $201 \mathrm{abcd}$ & 334 abcde & $1 \mathrm{a}$ & $8 \mathrm{a}$ & $1,488 \mathrm{~h}$ & $3,413 \mathrm{~h}$ & $55 \mathrm{abc}$ & $41 \mathrm{abc}$ & $15 \mathrm{ab}$ & $83 a b c$ & $0 \mathrm{a}$ & 347 bcdefg \\
\hline 18 & 587 efg & 503 abcde & $53 \mathrm{a}$ & $50 \mathrm{a}$ & $23 \mathrm{a}$ & $231 \mathrm{abcd}$ & $40 \mathrm{ab}$ & $25 \mathrm{ab}$ & $160 \mathrm{~d}$ & $146 a b c$ & $11 \mathrm{ab}$ & $150 \mathrm{abc}$ \\
\hline 19 & $83 \mathrm{ab}$ & $87 \mathrm{ab}$ & $24 \mathrm{a}$ & $216 \mathrm{a}$ & $180 \mathrm{abc}$ & $1,053 \mathrm{ef}$ & $17 \mathrm{ab}$ & $45 a b c$ & $1 \mathrm{a}$ & $88 \mathrm{abc}$ & $0 \mathrm{a}$ & 373 bcdefg \\
\hline 20 & $545 \mathrm{def}$ & $764 \mathrm{de}$ & $16 \mathrm{a}$ & $12 \mathrm{a}$ & $35 \mathrm{ab}$ & $187 \mathrm{abcd}$ & $27 \mathrm{ab}$ & $7 \mathrm{a}$ & $0 \mathrm{a}$ & $3 \mathrm{a}$ & $164 \mathrm{~d}$ & $433 \mathrm{cdefg}$ \\
\hline 21 & $733 \mathrm{fg}$ & 700 bcde & $13 \mathrm{a}$ & $7 \mathrm{a}$ & $193 \mathrm{abc}$ & $800 \mathrm{def}$ & 140 bcde & $237 \mathrm{de}$ & $0 \mathrm{a}$ & $30 \mathrm{a}$ & $20 \mathrm{ab}$ & 680 ghij \\
\hline 22 & $157 \mathrm{abc}$ & 240 abcd & $112 \mathrm{a}$ & $221 \mathrm{a}$ & $61 \mathrm{ab}$ & 203 abcd & $1 \mathrm{a}$ & $13 \mathrm{a}$ & $13 \mathrm{ab}$ & $45 \mathrm{a}$ & $4 \mathrm{ab}$ & 337 abcdef \\
\hline 23 & 307 abcde & 267 abcde & $87 \mathrm{a}$ & $21 \mathrm{a}$ & 808 efg & $3,060 \mathrm{~h}$ & $527 \mathrm{f}$ & $444 \mathrm{f}$ & $73 \mathrm{c}$ & $42 \mathrm{a}$ & $8 \mathrm{ab}$ & $813 \mathrm{ijk}$ \\
\hline 24 & $172 a b c$ & 208 abcd & $24 \mathrm{a}$ & $92 \mathrm{a}$ & $4 \mathrm{a}$ & $27 \mathrm{a}$ & $0 \mathrm{a}$ & $0 \mathrm{a}$ & $31 a b c$ & $152 \mathrm{abc}$ & $14 \mathrm{ab}$ & 253 abcde \\
\hline 25 & $449 \mathrm{cdef}$ & 350 abcde & $7 \mathrm{a}$ & $33 \mathrm{a}$ & $19 \mathrm{a}$ & $127 \mathrm{abcd}$ & $32 \mathrm{ab}$ & $23 \mathrm{ab}$ & $0 \mathrm{a}$ & $10 \mathrm{a}$ & $10 \mathrm{ab}$ & 253 abcde \\
\hline 26 & 316 abcde & $763 \mathrm{de}$ & $40 \mathrm{a}$ & $30 \mathrm{a}$ & $861 \mathrm{fg}$ & $2,153 \mathrm{~g}$ & $24 \mathrm{ab}$ & $30 \mathrm{ab}$ & $0 \mathrm{a}$ & $63 a b c$ & $0 \mathrm{a}$ & $887 \mathrm{jk}$ \\
\hline 27 & $120 a b c$ & 397 abcde & $7 \mathrm{a}$ & $33 \mathrm{a}$ & $16 \mathrm{a}$ & $144 \mathrm{abc}$ & $35 \mathrm{ab}$ & 215 cde & $0 \mathrm{a}$ & $93 a b c$ & $54 \mathrm{bc}$ & 275 abcde \\
\hline 28 & $39 a$ & $67 \mathrm{a}$ & $8 \mathrm{a}$ & $0 \mathrm{a}$ & $1,471 \mathrm{~h}$ & $4,173 \mathrm{i}$ & $188 \mathrm{de}$ & 197 bcde & $0 \mathrm{a}$ & $53 \mathrm{ab}$ & $7 \mathrm{ab}$ & 633 fghij \\
\hline 29 & 424 bcdef & $2,080 \mathrm{f}$ & $13 \mathrm{a}$ & $127 \mathrm{a}$ & $67 \mathrm{ab}$ & 507 abcde & $53 \mathrm{abc}$ & $7 \mathrm{a}$ & $0 \mathrm{a}$ & $7 \mathrm{a}$ & $20 \mathrm{ab}$ & 493 efgh \\
\hline 30 & $28 \mathrm{a}$ & $31 \mathrm{a}$ & $20 \mathrm{a}$ & $48 \mathrm{a}$ & $372 \mathrm{~cd}$ & $720 \mathrm{cde}$ & $265 \mathrm{e}$ & $551 \mathrm{f}$ & $0 \mathrm{a}$ & $213 b c$ & $0 \mathrm{a}$ & 283 abcde \\
\hline 31 & $65 \mathrm{ab}$ & $55 \mathrm{a}$ & $5 \mathrm{a}$ & $5 \mathrm{a}$ & $239 a b c$ & $903 \mathrm{ef}$ & $57 \mathrm{abc}$ & $61 \mathrm{abc}$ & $20 a b c$ & $75 \mathrm{abc}$ & $0 \mathrm{a}$ & 247 abcde \\
\hline 32 & $60 \mathrm{a}$ & $87 \mathrm{ab}$ & $7 \mathrm{a}$ & $117 \mathrm{a}$ & $412 \mathrm{~cd}$ & $783 \mathrm{def}$ & $53 \mathrm{abc}$ & $70 \mathrm{abcd}$ & $13 \mathrm{ab}$ & $30 \mathrm{a}$ & $0 \mathrm{a}$ & 280 abcde \\
\hline 33 & $0 \mathrm{a}$ & $0 \mathrm{a}$ & $72 \mathrm{a}$ & $95 \mathrm{a}$ & $883 \mathrm{fg}$ & $37 \mathrm{a}$ & $108 \mathrm{abcd}$ & $25 \mathrm{ab}$ & $67 \mathrm{bc}$ & $61 \mathrm{abc}$ & $0 \mathrm{a}$ & $72 \mathrm{ab}$ \\
\hline 34 & $133 \mathrm{abc}$ & $760 \mathrm{de}$ & $27 \mathrm{a}$ & $217 \mathrm{a}$ & 307 bd & $773 \mathrm{de}$ & $5 \mathrm{a}$ & $13 \mathrm{a}$ & $28 \mathrm{abc}$ & $3 \mathrm{a}$ & $0 \mathrm{a}$ & 416 cedfg \\
\hline 35 & $79 \mathrm{ab}$ & $120 a b c$ & $97 \mathrm{a}$ & $20 \mathrm{a}$ & $1,031 \mathrm{~g}$ & $2,110 \mathrm{~g}$ & $0 \mathrm{a}$ & $27 \mathrm{ab}$ & $0 \mathrm{a}$ & $80 a b c$ & $0 \mathrm{a}$ & $1,107 \mathrm{k}$ \\
\hline 36 & $147 \mathrm{abc}$ & 200 abcd & $27 \mathrm{a}$ & $167 \mathrm{a}$ & $167 \mathrm{abc}$ & $1,013 \mathrm{ef}$ & $7 a$ & $20 \mathrm{a}$ & $13 \mathrm{ab}$ & $147 \mathrm{abc}$ & $0 \mathrm{a}$ & $867 \mathrm{jk}$ \\
\hline 37 & $51 \mathrm{a}$ & $140 \mathrm{abcd}$ & $15 \mathrm{a}$ & $0 \mathrm{a}$ & $20 \mathrm{a}$ & $28 \mathrm{a}$ & $0 \mathrm{a}$ & $0 \mathrm{a}$ & $0 \mathrm{a}$ & $0 \mathrm{a}$ & $0 \mathrm{a}$ & $93 \mathrm{ab}$ \\
\hline 38 & $15 \mathrm{a}$ & $17 \mathrm{a}$ & $32 \mathrm{a}$ & $7 \mathrm{a}$ & $15 \mathrm{a}$ & $77 \mathrm{ab}$ & $193 \mathrm{de}$ & $263 \mathrm{e}$ & $0 \mathrm{a}$ & $24 \mathrm{a}$ & $0 \mathrm{a}$ & 248 abcde \\
\hline
\end{tabular}

y Genera: Cric = Criconemella, Helic $=$ Helicotylenchus, Tylen $=$ Tylenchorhynchus, Hoplo $=$ Hoplolaimus, Het $\mathrm{J}=$ Heterodera juveniles, Melo $\mathrm{J}=$ Meloidogyne juveniles, and NSB = non-stylet-bearing, summer. Letters represent means comparison groups within each column based on Waller-Duncan test ( $\alpha$ $=0.05$ ).

${ }^{\mathrm{z}}$ Site numbers refer to individual golf courses sampled as listed in Table 1. 
There was a substantial amount of variability in nematode population levels between the golf courses surveyed. However, mean separation may have been more distinct had more samples been surveyed from each site. The variability that was observed did not appear to be due to geographical differences because there were numerous sites in all three states surveyed that had either relatively high or low levels of parasitic nematodes. A majority of the sites that had higher than average levels of nematodes were from the courses that had historically high levels in the past, based on previous diagnostic data. This would indicate that, in the absence of chemical treatment, nematode population trends are relatively stable over time. In addition, many of the sites with higher levels of nematodes were from older greens, on courses that had been established for over 20 years. It has been suggested that green age could be a determining factor in nematode populations levels (21); therefore, this may be a reason for some of the differences observed in this survey.

The seasonal fluctuation observed for each nematode genus is consistent with previous findings for these genera $(5,9)$. Although there was some variability between sampling sites, Davis et al. (5) found that levels of Criconemella and Helicotylenchus spp. nematodes generally were highest in the spring and fall. In this study, we found that, at most sampling sites, levels of both Criconemella and Helicotylenchus spp. were similar in the spring and summer, but rose in the fall sampling (Fig. 2). Lucas et al. (9) observed that Tylenchorhynchus levels increased toward the end of the summer and declined into fall, as was the case in our study. Lucas et al. also found that Hoplolaimus densities were highest in June, but declined through the summer and rose again into the fall months. We saw no significant increase of Hoplolaimus spp. during the entire seasons; however, population levels of this nematode were low relative to the other nematodes studied. In this study, individual data between sampling sites did vary somewhat, especially where counts were well below threshold, but the results of our study combined with the previous studies mentioned suggest that the seasonal fluctuations of most of the nematode genera may be predictable, even over a

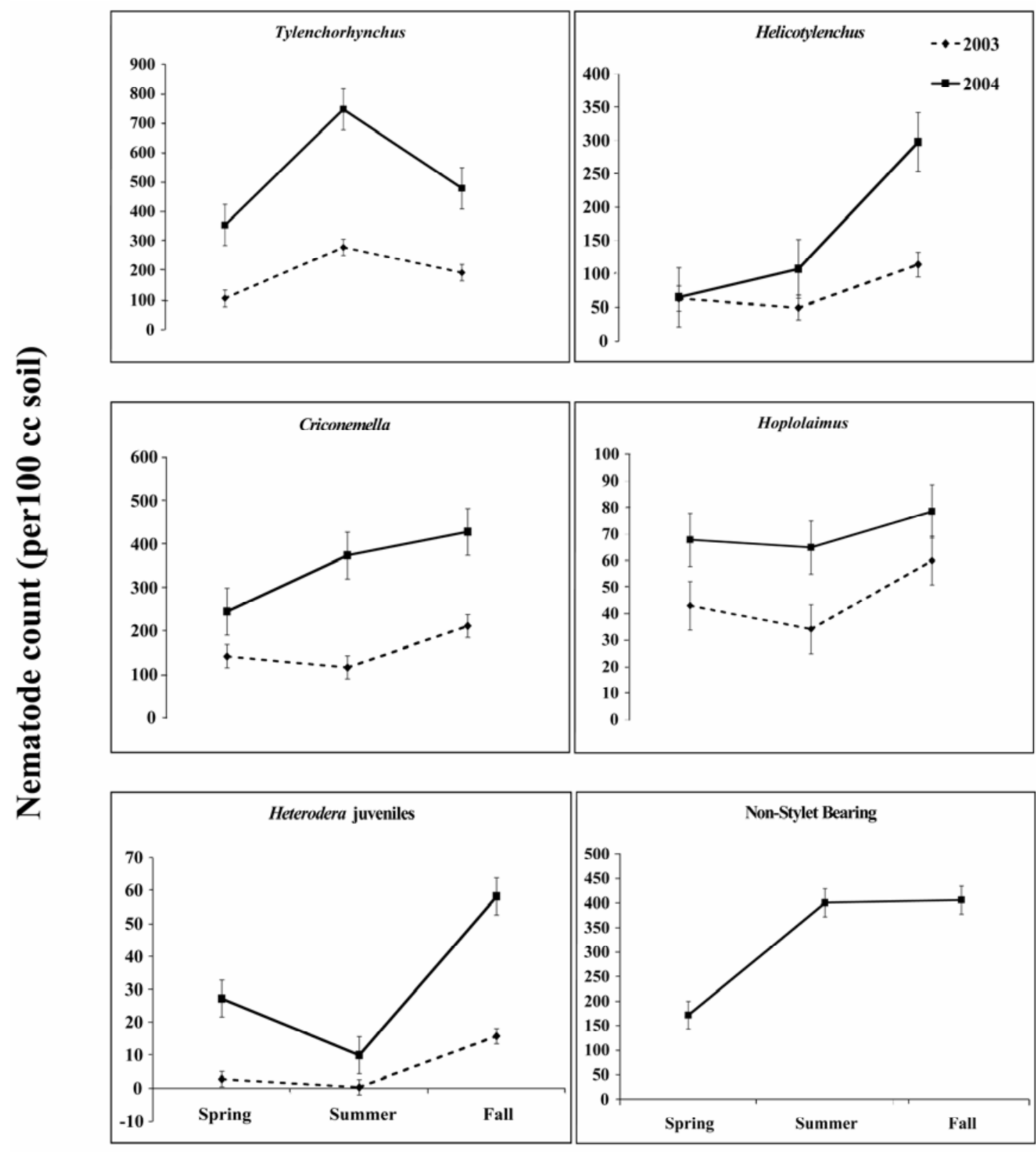

Sampling season

Fig. 2. Seasonal fluctuation of nematode populations in 2003 and 2004 expressed as nematodes per $100 \mathrm{~cm}^{3}$ of soil, averaged across all samples. 
relatively wide geographical area. These results differ from the findings of Wick (23), who observed that changes in population trends over a season were not consistent from one green to another. However, in Wick's study, he surveyed a broader geographical range of golf courses, including many parts of northern New England, where the climate is much more inconsistent between regions. Those somewhat extreme differences in climate between sampling sites may have increased the variability observed in his study. In this study, we surveyed primarily coastal southern New England, where the differences in climate are much more subtle. Additionally, this study surveyed over three times as many sites as did Wick's study, and that may have led to more consistent findings. Even though the nematode population levels were significantly different between 2003 and 2004 in our study, the pattern of seasonal variability we observed was similar between the 2 years. That indicates that seasonal fluctuation patterns of nematode genera may be constant between different seasons.

The differences in nematode population levels between 2003 and 2004 were consistent for all but two of the genera studied. There were more nematodes in the second season, even as early as the spring sampling, for Tylenchorhynchus, Criconemella, and Heterodera spp. We feel that this difference may have been due to extremely high moisture levels in the early part of the growing season of the first sampling year. Weather data was obtained from the National Oceanic and Atmospheric Administration for the various regions that were sampled (data not shown) and observed for rainfall and temperature variations. In spring 2003, both prior to and following the first two samplings, total rainfall in much of the southern New England regions was above average. This may not have allowed for the soil to dry out at any time during the spring and summer months. Because nematodes are adversely affected by extreme soil moisture $(2,13,22)$, saturation of the soil likely would inhibit movement and, potentially, survival of the nematodes. In the 2004 season, rainfall was above average only during the month of April, whereas the remaining months had precipitation levels that were at or below average for most of the areas surveyed. Under natural conditions, the moisture level may have been too dry for nematode survival; however, with the artificial irrigation that golf course greens receive (sometimes daily), the moisture was most likely kept at an ideal level for the nematodes. Differences in average, maximum, and minimum temperatures between the two sampling years were minimal, suggesting that temperature may not have played a role in the differences observed between 2003 and 2004. However, average and extreme temperature readings do not take into account the duration of freezing and thawing periods that may have occurred in either year, which may have impacted the ability of nematodes to successfully overwinter in the 2003 season.

The results of this research suggest that plant-parasitic nematodes are present, often in quantities above threshold levels, on golf course greens in southern New England. Although seasonal fluctuation of nematode populations was found to be relatively stable between sampling sites, there is a high degree of variability in the populations of nematode genera at different sites. This may suggest that other physical or biological factors likely are involved in determining nematode population dynamics in golf course greens soils.

\section{LITERATURE CITED}

1. Bekal, S., and Becker, J. O. 2000. Population dynamics of the sting nematode in California turfgrass. Plant Dis. 84:1081-1084.

2. Brown, F. N. 1933. Flooding to control rootknot nematodes. J. Agric. Res. 47:883-888.

3. Chastagner, G. A., and McElroy, F. D. 1984. Distribution of plant-parasitic nematodes in putting green turfgrass in Washington. Plant Dis. 68:151-153.

4. Christians, N. 2004. Fundamentals of Turfgrass Management, 2nd ed. John Wiley and Sons, Hoboken, NJ.

5. Davis, R. F., Kane, R. T., Wilkinson, H. T., and Noel, G. R. 1994. Population fluctuations of three nematode genera in putting greens in Northern Illinois. J. Nematol. 26:522-530.

6. Duncan, L. W., and McSorley, R. 1987. Modeling nematode populations. Pages 377-389 in: Vistas on Nematology. J. A. Veech and D. W. Dickson, eds. Society of Nematologists, Hyattsville, MD.

7. Fushtey, S. G., and McElroy, F. D. 1977. Plant parasitic nematodes in turfgrass in southern British Columbia. Can. Plant Dis. Surv. 57:5456.
8. Jenkins, W. R. 1964. A rapid centrifugalflotation technique for separating nematodes from soil. Plant Dis. Rep. 48:692.

9. Lucas, L. T., Barker, K. R., and Blake, C. T. 1978. Seasonal changes in nematode densities on bentgrass golf greens in North Carolina. Plant Dis. Rep. 62:373-376.

10. Martin, B., and Golden, J. 2000. When dealing with turf problems in the southeast-don't forget nematodes. South Carolina Turfgrass Foundation Newsl. July-September 2000.

11. Murdoch, C. L., Tashiro, H., and Harrison, M B. 1978. Plant-parasitic nematodes associated with golf putting-green turf in New York. Plant Dis. Rep. 62:85-87.

12. Nelson, E. B. 1995. Nematode disorders of turfgrasses: How important are they? Turfgrass Trends 4:1-20.

13. Norton, D. C. 1978. Ecology of Plant-Parasitic Nematodes. John Wiley and Sons, New York.

14. Perry, V. G., and Smart, G. C, Jr. 1970. Nematode problems of turfgrasses in Florida and their control. Proc. Fla. State Hortic. Soc. 83:489-492.

15. Riedel, R. M. 1980. Nematode problems of northern turfgrasses. Pages 59-62 in: Advances in Turfgrass Pathology. B. G. Joyner and P. O. Larsen, eds. Harcourt Brace Jovanovich, Duluth, MN.

16. Smiley, R.W., Dernoeden, P. H., and Clarke, B. B. 1992. Compendium of Turfgrass Diseases, 2nd ed. American Phytopathological Society Press, St. Paul, MN.

17. Sumner, D. R. 1967. Nematodes in bluegrass. Plant Dis. Rep. 51:457-460.

18. Taylor, D. P., Britton, M. P., and Hechler, H. C. 1963. Occurrence of plant parasitic nematodes in Illinois golf greens. Plant Dis. Rep. 47:134135.

19. Todd, T. C., and Tisserat, N. A. 1990. Occurrence, spatial distribution, and pathogenicity of some phytoparasitic nematodes on creeping bentgrass putting greens in Kansas. Plant Dis. 74:660-663.

20. Troll, J., and Tarjan, A. C. 1954. Widespread occurrence of root parasitic nematodes in golf course greens in Rhode Island. Plant Dis. Rep. 38:342-344.

21. Walker, N. R., Goad, C. L., Zhang, H., and Martin, D. L. 2002. Factors associated with populations of plant-parasitic nematodes in bentgrass putting greens in Oklahoma. Plant Dis. 86:764-768.

22. Wallace, H. R. 1964. The Biology of PlantParasitic Nematodes. St. Martin's Press, New York.

23. Wick, R. L. 1989. Population dynamics of nematodes in putting greens. Golf Course Manage. 57:100-112.

24. Winchester, J. A., and Burt, E. O. 1964. The effect and control of sting nematodes on Ormond Bermuda grass. Plant Dis. Rep. 48:625628.

25. Yu, Q., Potter, J. W., and Gilby, G. 1998. Plantparasitic nematodes associated with turfgrass in golf courses in southern Ontario. Can. J. Plant Pathol. 20:304-307. 